\title{
KARAKTERISTIK VOLUME \& DURASI PARKIR DI PUSAT PERBELANJAAN MEGA MALL KOTA SORONG
}

\author{
Nurul Puteri H. Matdoan ${ }^{1)}$, Achmad Ja'far, ${ }^{2)}$ Agus Sukrisman ${ }^{3)}$ \\ ${ }^{1)}$ Program Studi Teknik Sipil Universitas Muhammadiyah Sorong \\ Jl. Pendidikan No. 27 Kota Sorong \\ Email: puterimatdoan@gmail.com
}

\begin{abstract}
Abstrak
Tempat parkir merupakan fasilitas umum dan penunjang di suatu pusat perbelanjaan. Mega Mall merupakan salah satu pusat perbelanjaan di Kota Sorong yang saat ini sedang menata fasilitas parkir yang dimiliki. Banyaknya bangunan-bangunan yang baru yang mempunyai tarikan dan bangkitan kendaraan yang cukup tinggi, seperti mall yang membuat semakin sempitnya ruang untuk pergerakan kendaraan yang ada di Kota Sorong aktivitas kendaraan roda empat misalnya. Durasi rata - rata kendaraan roda 4 berparkir pada pukul 16.00 - 18.00 WIT adalah 15 menit.Volume parkir di halaman parkir dimana jumlah kendaraan masuk yaitu sebanyak 76 , sedangkan jumlah kendaraan yang sedang terparkir sebanyak 22 unit, sehingga jumlah volume parkir yaitu 101 unit
\end{abstract}

Kata Kunci : Parkir, Kendaraan, Pusat Perbelanjaan

\section{PENDAHULUAN}

Kota Sorong sebagai kota sentral ekonomi di daerah bagian barat Papua adalah kota yang mempunyai perkembangan yang tumbuh dengan pesat, oleh karena itu maka pemerintah harus menyediakan sarana dan prasarana kota untuk menunjang kelancaran dari pertumbuhan kota Sorong itu sendiri. Dalam hal perkembangan kota yang paling menonjol dan pesat perkembangannya adalah pusat perbelanjaan. Di kota Sorong sedikitnya terdapat lima pusat perbelanjaan yang kesemuanya masuk dalam kategori pusat perbelanjaan besar. Salah satu dari pusat perbelanjaan yang ada dipusat kota Sorong adalah Mega Mall yang merupakan salahsatu tempat penjualan barang yang lumayan padat dikota Sorong.

Pusat perbelanjaan Mega Mall memiliki ruang luar yang cukup luas untuk menampung kebutuhan ruang parkir pengunjungnya. Pusat perbelanjaan Mega Mall saat ini menyediakan dua zona parkir. Zona pertama digunakan untuk parkir kendaraan roda dua dan zona kedua digunakan untuk parkir kendaraan roda empat. Tetapi pengaturan yang ada tidak memberikan informasi yang jelas pada pengunjung, baik penempatan parkir maupun sirkulasinya dan pada harihari tertentu lahan parkir yang ada tidak dapat menampung kendaraan yang masuk. Pada artikel ini peneliti mengkaji volume dan durasi parkir di Mega Mall. Analisis dilakukan dengan meninjau karakteristik parkir pada pusat perbelanjaan yang diterapkan untuk kondisi eksisting. Dari hasil analisis disajikan untuk mengetahui tingkat durasi parker kendaraan roda 4 di tempat perbelanjaan di Mega Mall dan untuk mengetahui luasan area parker di Mega Mall. 


\section{METODOLOGI}

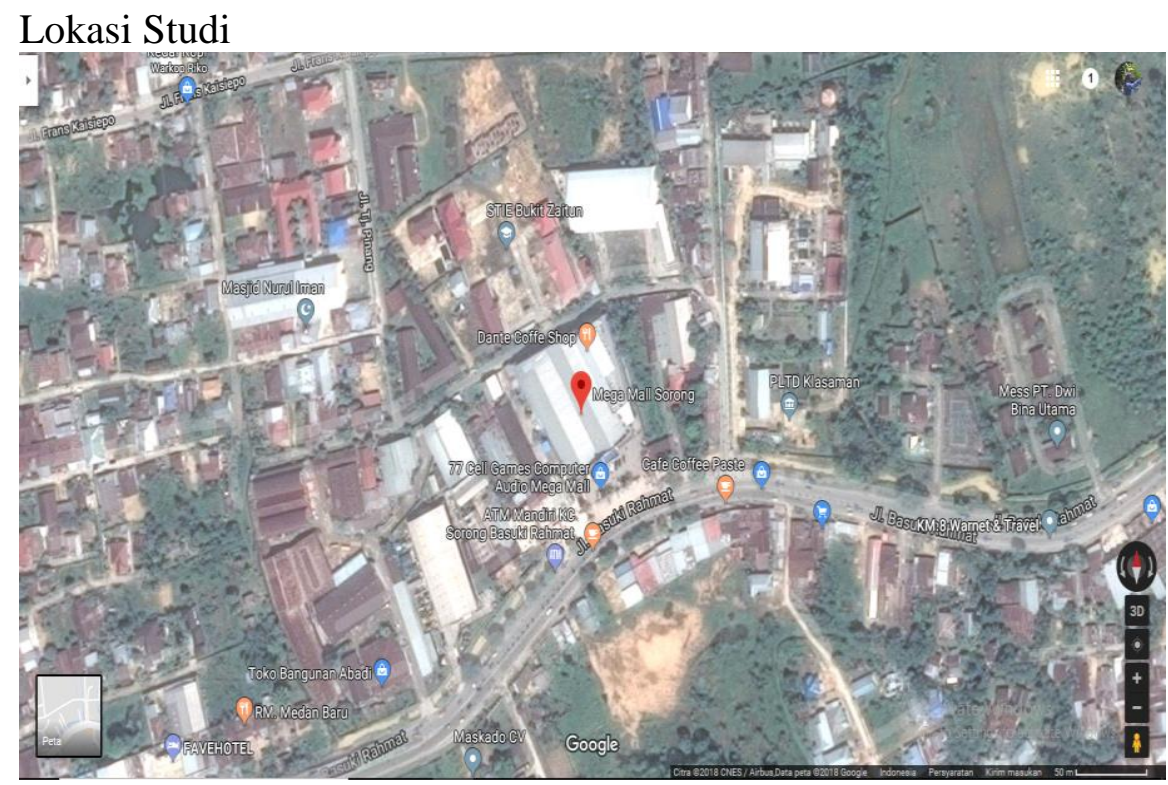

Gambar 1. Lokasi studi

Tahapan penyusunan artikel:

1. Penentuan tema

2. Pengambilan data dari tugas Makalah

3. Analisa data

4. Membuat kesimpulan untuk menjawab tujuan penulisan artikel

Semua metode penulisan dan analisa dalam artikel ilmiah ini merujuk pada panduan penulisan tugas akhir Fakultas Teknik Universitas Muhammadiyah Sorong tahun 2014 (Pristianto, Amri, \& Rusdi, 2014).

\section{HASIL DAN PEMBAHASAN}

Penelitian dengan tema yang sama.

Hasil penelitian terkait tema artikel ini adalah sebagai berikut :

Menurut Ja'far (2018) yang meneliti tentang, kesimpulan yang dapat diambil dari uraian ini adalah :

a. Dari hasil pengamatan tampak bahwa jumlah kendaraan roda 4 berparkir pada pukul 16.00 - 18.00 WIT sebanyak 76 unit.

b. Hasil pengamatan tampak bahwa durasi rata - rata kendaraan roda 4 berparkir pada pukul $16.00-18.00$ WIT adalah 15 menit..

c. Volume parkir di halaman parkir dimana jumlah kendaraan masuk yaitu sebanyak 76, sedangkan jumlah kendaraan yang sedang terparkir sebanyak 22 unit, sehingga jumlah volume parkir yaitu 101 unit. 


\section{$\underline{\text { Analisa }}$}

Antusias masyarakat untuk mengunjungi pusat perbelanjaan Mega Mall saat ini cukup tinggi. Namun penyediaan fasilitas parkir di pusat perbelanjaan ini kurang diperhatikan. Hal ini ditunjukkan dengan pengaturan ruang parkir roda empat yang terbagi-bagi menjadi beberapa tempat. Namun begitu, hal ini tidak membuat para pengunjung mengurungkan niat untuk berbelanja di pusat perbelanjaan tersebut. Dilihat dari banyaknya kendaraan roda empat yang memarkirkan kendaraan mereka dengan durasi yang cukup lama.

\section{KESIMPULAN}

Kesimpulan yang dapat diambil dari para peneliti di atas adalah volume parkir yang terdapat pada pusat perbelanjaan Mega Mall adalah sebanyak 101 unit.Ketersediaan ruang parkir di pusat perbelanjaan tersebut sudah memenuhi kebutuhan ruang parkir. Hal ini terbukti dengan tidak adanya kendaraan yang tertolak pada saat akumulasi parkir maksimal terjadi. Namun terjadi kekosongan ruang parkir yang cukup banyak yang disebabkan adanya perbedaan permintaan ruang parkir yang signifikan.

\section{DAFTAR PUSTAKA}

1. Ja'far, A. (2018). Hasil survey analisa tanggal 04 juni 2018.

2. https://www.google.com/url? sa=t\&rct=j\&q=\&esrc=s\&source=web\&cd=3\&cad=r ja\&uact=8\&ved=0ahUKEwjxv4ri87zbAhVZU30KHTqyBKYQFgg5MAI\&url=h ttp\%3A\%2F\%2Ferepo.unud.ac.id\%2F9267\%2F3\%2F18455bb240e4db702bb7f2 ae2697bf87.pdf\&usg=AOvVaw04IPEZ0GpwprCGwsuMBjaO

3. Pristianto, H., Amri, I., \& Rusdi, A. (2018). Pedoman Penulisan Tugas Akhir Fakultas Teknik Universitas Muhammadiyah Sorong. 